\title{
Root Growth and Nitrate Uptake of Three Different Catch Crops in Deep Soil Layers
}

\author{
H. L. Kristensen* and K. Thorup-Kristensen
}

\begin{abstract}
Catch crops can reduce $\mathrm{NO}_{3}$ losses from leaching, but little is known about the importance of deep rooting for the efficiency of $\mathrm{NO}_{3}$ depletion. In a field experiment, we investigated the $\mathrm{N}$ uptake and root growth of three types of catch crops using minirhizotrons (glass tubes of 70-mm o.d.) reaching $2.4 \mathrm{~m}$. Our purpose was to evaluate minirhizotron methodology and the importance of deep rooting in the ability of catch crops to take up $\mathrm{NO}_{3}$ from deep soil layers. Nitrogen uptake was studied over a 6-d period at the end of October by injection of ${ }^{15} \mathrm{NO}_{3}$ at four depths in the ranges: 0.4 to $1,0.5$ to 1.4 , and 1 to $2.5 \mathrm{~m}$ under Italian ryegrass (Lolium multiflorum Lam.), winter rye (Secale cereale $\mathbf{L}$.), and fodder radish (Raphanus sativus L. var. oleiformis Pers.), respectively. The root depth of the three species were $0.6,1.1$, and more than $2.4 \mathrm{~m}$, respectively. No ${ }^{15} \mathrm{~N}$ was taken up from placements below root depth, and linear relationships were found between root density and ${ }^{15} \mathrm{~N}$ uptake from different depths. Residual soil $\mathrm{NO}_{3}$ of 18,59 , and $87 \mathrm{~kg} \mathrm{~N} \mathrm{ha}^{-1}$ was left under fodder radish, winter rye, and ryegrass, respectively. The measurements obtained with the minirhizotron method were highly relevant for evaluating $\mathbf{N}$ uptake from different soil layers, and root depths of the catch crops were important for $\mathbf{N}$ depletion. Knowledge about root growth and $\mathrm{N}$ uptake in deep soil layers may be utilized when designing crop rotations with improved $\mathrm{N}$ use efficiency. Where $\mathrm{N}$ has been left by a preceding crop and leached to deeper soil layers, it may be recycled by deep-rooted catch crops.
\end{abstract}

E LEVATED LEACHING OF $\mathrm{NO}_{3}$ from agricultural areas is an ever-present problem because of the eutrophication of surface waters and the contamination of ground water. Growing catch crops, also called cover crops, during the autumn, however, is one way of reducing losses of $\mathrm{NO}_{3}$ by leaching. Catch crops take up and retain the $\mathrm{NO}_{3}$ left in the soil by the preceding crop, that is, $\mathrm{NO}_{3}$ that is otherwise lost from the root zone by leaching (Meisinger et al., 1991; Thorup-Kristensen et al., 2003). The $\mathrm{NO}_{3}$ is returned to the surface soil layer when the catch crop is killed; the catch crop thus acting as fertilizer for the next crop in rotation. These beneficial effects have caused extensive use of catch crops in some regions and their use is encouraged by legislation in, for example, Denmark.

The efficiency of catch crops to retain $\mathrm{NO}_{3}$ differs depending on factors such as length of growing season and capacity for $\mathrm{N}$ uptake (e.g., Richards et al., 1996). The importance of catch crop root depth in reducing $\mathrm{NO}_{3}$ leaching to ground water has been largely neglected, with most studies of soil $\mathrm{NO}_{3}$ depletion covering only the top $1 \mathrm{~m}$ or less of the soil profile (e.g., Vos et

H.L. Kristensen and K. Thorup-Kristensen, Danish Institute of Agricultural Sciences, Dep. of Horticulture, Kirstinebjergvej 10, DK5792 Årslev, Denmark. Received 12 Feb. 2003. *Corresponding author (Hanne.Kristensen@agrsci.dk).

Published in Soil Sci. Soc. Am. J. 68:529-537 (2004).

(c) Soil Science Society of America

677 S. Segoe Rd., Madison, WI 53711 USA al., 1998). Cultivated plants are thought to have the major part of their root system within this depth, but because of the high mobility of the $\mathrm{NO}_{3}$ ion in soil solution it is worthwhile studying root growth in deeper soil layers even if root density is low. Over the time span of a growing season, just a few roots may be enough for the uptake of large amounts of $\mathrm{NO}_{3}$ (Robinson, 1986; Strebel and Duynisveld, 1989), and thus for reducing $\mathrm{NO}_{3}$ leaching to ground water (Thorup-Kristensen, 2001).

Studies have shown that many species extend roots to considerable depths. In a literature review, the average maximum rooting depth of arable crops on a global scale was estimated to be $2.1 \mathrm{~m}$ (Canadell et al., 1996); another review found the expected maximum rooting depth in the range 1 to $3 \mathrm{~m}$ in 44 out of 53 annual crops (Borg and Grimes, 1986). Studies of the root growth of catch crops below 1-m depth have shown large differences in root depth and distribution from one species to the next (Barraclough, 1989; Materechera et al., 1993; Thorup-Kristensen, 2001).

Investigations of soil $\mathrm{NO}_{3}$ and plant $\mathrm{N}$ uptake have also indicated root activity and $\mathrm{N}$ uptake by annual crops and catch crops in soils below 1-m depth. Significant N uptake has been found at 0.9 to $1.5 \mathrm{~m}$ for winter wheat (Triticum aestivum L.), winter barley (Hordeum vulgare L.), sugarbeet (Beta vulgaris L. var. altissima Döll), corn (Zea mays L.), and fodder radish (Kuhlmann et al., 1989; Strebel and Duynisveld, 1989; Wiesler and Horst, 1994; Huang et al., 1996; Thorup-Kristensen, 2001). Studies from Nebraska have shown $\mathrm{N}$ uptake from $1.8 \mathrm{~m}$ by corn and from as deep as $2.4 \mathrm{~m}$ by sugarbeet (Gass et al., 1971; Peterson et al., 1979). These findings were based either on indirect evidence from changes in residual soil $\mathrm{N}$ pools, or on study of ${ }^{15} \mathrm{~N}$ uptake from different soil layers over long periods, such as a growing season. In only a few studies has $\mathrm{N}$ uptake been compared with root growth at more than 1-m depth (Kuhlmann et al., 1989; Strebel and Duynisveld, 1989; Wiesler and Horst, 1994; Thorup-Kristensen, 2001), and the experimental approaches in these studies were not optimal for more detailed examination of root system-plant $\mathrm{N}$ uptake relationships. The long-term nature of this kind of experiment has an unknown influence from $\mathrm{N}$ leaching and $\mathrm{N}$ microbial processes such as mineralization-immobilization and denitrification.

In studying root growth, the use of angled minirhizotrons enables frequent and nondestructive sampling of information on root depth and distribution (Smit et al., 2000). The method involves inserting transparent tubes into the ground and in situ counting of roots at the interface between the tube wall and the soil. The use of angled minirhizotrons has been questioned, however, in comparison with destructive core sampling, where roots are washed from the soil samples. It has been concluded that root density in deeper soil layers tends 
to be overestimated with the minirhizotron method, presumably due to preferential growth of roots in voids along minirhizotrons (e.g., Parker et al., 1991; Heeraman and Juma, 1993). In such studies, however, measurements rarely extend to the bottom of the root zone, and the validity of the conclusions that can be drawn from comparisons is thus weakened. A more appropriate test of the use of minirhizotrons would be to compare root depth and distribution estimated by minirhizotrons with the results of plant $\mathrm{N}$ uptake from different soil layers (Thorup-Kristensen, 2001). This would show the effective root depth and distribution in terms of $\mathrm{N}$ uptake. Plant $\mathrm{N}$ uptake could be measured using ${ }^{15} \mathrm{~N}$ injection methodology as described by Gass et al. (1971) and Huang et al. (1996), who injected ${ }^{15} \mathrm{~N}$ labeled $\mathrm{NO}_{3}$ solution into different soil layers to show relative differences in $\mathrm{N}$ uptake between layers. Contrary to these studies, such a ${ }^{15} \mathrm{~N}$ experiment could be short-term to enable comparison of root distribution with $\mathrm{N}$ uptake rates at a certain point in time. Furthermore, this would minimize the influences on results from $\mathrm{N}$ mineralization processes and $\mathrm{N}$ leaching.

In this study, we combined minirhizotron studies of root growth with ${ }^{15} \mathrm{~N}$ studies of $\mathrm{N}$ uptake from various soil layers over a $6-\mathrm{d}$ period. The aims were threefold: (i) to test the relevance of root measurements obtained by the minirhizotron method against measured root system $\mathrm{N}$ uptake; (ii) to investigate root growth and efficiency for $\mathrm{N}$ uptake of three catch crops expected to have shallow, intermediate, and deep root growth; and (iii) to quantify the relationship between root distribution and short-term $\mathrm{N}$ uptake by catch crops in deep soil layers.

\section{MATERIALS AND METHODS}

\section{Field Site and Experiment}

A field experiment was established to study the root growth and $\mathrm{N}$ uptake of catch crops at the Research Centre Aarslev $\left(10^{\circ} 27^{\prime} \mathrm{E}, 55^{\circ} 18^{\prime} \mathrm{N}\right)$ on the Danish island of Funen. The soil was a sandy loam (Typic Agrudalf) with the 0- to $0.25-\mathrm{m}$ soil layer containing $1.8 \% \mathrm{C}, 0.16 \% \mathrm{~N}, 15 \%$ clay, $27 \%$ silt, and $55 \%$ sand; and the 0.25 - to 1 -m layer containing $0.4 \%$ C, $0.05 \%$ N, $20 \%$ clay, $28 \%$ silt, and $52 \%$ sand (Thorup-Kristensen, 2001). The $\mathrm{pH}_{\mathrm{CaCl} 2}$ was 7.1, 7.4, 6.6, 7.5, and 7.9; the soil contained 27, 17, 16, 17, and $11 \mathrm{mg} \mathrm{P} \mathrm{kg}{ }^{-1}$ soil (extracted with $0.5 \mathrm{M} \mathrm{NaHCO}_{3}$ ), and $123,95,95,80$, and $74 \mathrm{mg} \mathrm{K} \mathrm{kg}^{-1}$ soil (extracted with $\mathrm{CH}_{3} \mathrm{COONH}_{4}$ ) in the 0 - to $0.5-, 0.5$ - to 1-, 1- to 1.5-, 1.5- to 2-, and 2- to 2.5-m layers, respectively (ThorupKristensen, unpublished data, 2003). Average annual precipitation $(624 \mathrm{~mm})$ and air temperature $\left(7.8^{\circ} \mathrm{C}\right)$ were recorded at a meteorological station at the research center (average 1961-1990). Daily precipitation and average daily temperature (average of hourly recorded air temperature at 2-m height) during the field experiment are shown in Fig. 1. The field had been under organic farming management since 1994, and had tile drains at $1 \mathrm{~m}$-depth. In the preceding winter, the field was covered by a mixture of ryegrass and red clover (Trifolium pratense L.) until plowing in December 1999, after which the soil was left bare until catch crops were sown. Italian ryegrass, winter rye, and fodder radish were sown on 8 Aug. 2000 in four replicate plots of 5 by $20 \mathrm{~m}$ in a complete randomized block design. Seeding densities were 20,120 , and $20 \mathrm{~kg} \mathrm{ha}^{-1}$ for ryegrass, winter rye, and fodder radish, respectively.

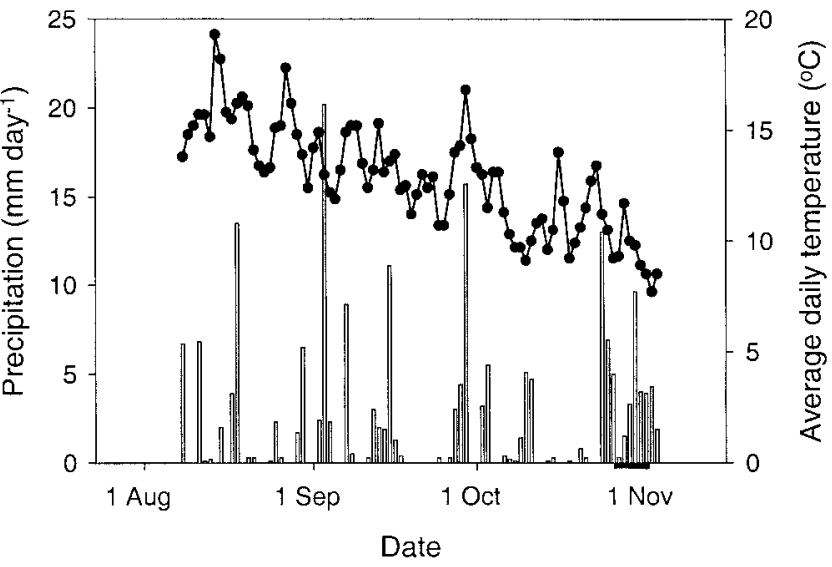

Fig. 1. Daily precipitation and temperature from sowing of catch crops on 8 August. The horizontal bar on the $x$-axis indicates the 6-d experimental period.

\section{Measurement of Root Growth}

Root growth was measured using minirhizotrons (glass tubes of 70-mm o.d.) inserted perpendicular to the direction of rows immediately after the catch crops were sown. The holes were drilled using a spiral auger with a diameter of $60 \mathrm{~mm}$ to remove most of the soil, followed by drilling with a 74-mm diameter piston auger. The slightly larger diameter of the piston auger was necessary to allow insertion of the minirhizotron due to swelling of the soil after drilling. Threemeter long minirhizotrons were placed at an angle of $30^{\circ}$ from the vertical and reached a depth of approximately $2.42 \mathrm{~m}$ into the soil. Two were installed in each plot, making a total of eight replicate minirhizotrons for each species of catch crop. The part of the minirhizotrons extending above soil surface was covered in black tape and the top end was capped. Root growth was registered using two replicate counting grids painted along the 3-m surface, one to the left-hand side and one to the right on the upper surface of the minirhizotron. Each grid consisted of a 3-m line crossed perpendicularly by lines of 40-mm length for every $40 \mathrm{~mm}$, thus creating a long row of 40 by $40 \mathrm{~mm}$ crosses along the minirhizotron. Each cross was numbered to determine the position in the soil. The roots at the interface between the minirhizotron wall and the soil were registered by filming with a mini-video camera along the counting grids.

The video films of roots were used to register three different measures of root growth: root depth, root intensity, and root frequency. Root depth was registered as the deepest root observed in each of the two counting grids on each rhizotron. Root intensity was registered as the total number of roots crossing the lines in each 40 by $40 \mathrm{~mm}$ cross (total of $80-\mathrm{mm}$ line). This was calculated as number of root intersections per meter line (intersections $\mathrm{m}^{-1}$ ) in a soil layer of 34.6- $\mathrm{mm}$ depth $\left[=\cos \left(30^{\circ}\right) \times 40 \mathrm{~mm}\right]$ due to the position of the tube $30^{\circ}$ from vertical. For calculation of root frequency, it was registered if any roots were crossing the lines in each 40 by $40 \mathrm{~mm}$ cross. The root frequency was calculated as the percentage of 40 by $40 \mathrm{~mm}$ crosses where roots had been observed within a given soil layer $(0.25 \mathrm{~m})$. The four measures obtained within each plot (two minirhizotrons with two grids each) were averaged for each plot. Root depth registration was initiated $4 \mathrm{wk}$ after sowing and ended after the ${ }^{15} \mathrm{~N}$ experiment on 3 Nov. 2000. Root intensity and frequency were measured on 23 Oct. 2000; that is, $2 \mathrm{~d}$ before the ${ }^{15} \mathrm{~N}$ injection experiment. Root depth penetration rates $\left(\mathrm{mm} \mathrm{d}^{-1}{ }^{\circ} \mathrm{C}^{-1}\right)$ were calculated, following Barraclough and Leigh (1984), as the slope of regression lines 


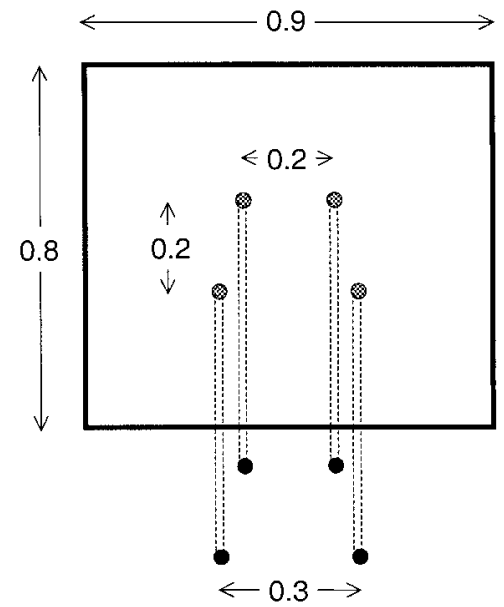

Fig. 2. Subplot for ${ }^{15} \mathrm{~N}$ injection at 1-m depth. Due to the angle of $30^{\circ}$ from vertical of the boring holes, the boring points on the soil surface (๑) are placed outside the subplot for harvest of plant material, while the points of deep ${ }^{15} \mathrm{~N}$ placement $(\otimes)$ are situated right under the subplot. The numbers indicate distances in meters.

of the average root depth versus accumulated average daily temperature from sowing (average of hourly measurements, base temperature of $0^{\circ} \mathrm{C}$ ).

\section{Deep Point Nitrogen-15 Injection}

Uptake of $\mathrm{N}$ was studied by deep point injection of ${ }^{15} \mathrm{NO}_{3}$ at four different depths under the catch crops, followed by sampling of plant biomass and analysis of ${ }^{15} \mathrm{~N}$ enrichment in the plant $\mathrm{N}$ pool. The ${ }^{15} \mathrm{NO}_{3}$ was applied on $25-26$ Oct. 2000 in four subplots within each plot, giving four replicate subplots for each depth and species. For each species, the injection depths were chosen to represent soil layers with medium, low, very low, and no roots, based on the preceding minirhizotron measurements of root depth. The depths for ryegrass were $0.4,0.6,0.8$, and $1 \mathrm{~m}$; for winter rye $0.5,0.8,1.1$, and $1.4 \mathrm{~m}$; and for fodder radish $1,1.5,2$, and $2.5 \mathrm{~m}$. The subplots $(0.9$ by $0.8 \mathrm{~m}$, equivalent to seven plant rows) used for injection at the four depths were randomly placed within each plot at a minimum distance of $2 \mathrm{~m}$. As shown in Fig. 2, the ${ }^{15} \mathrm{NO}_{3}$ was injected into each subplot through four holes at a distance in all directions of at least $0.3 \mathrm{~m}$ from the deep ${ }^{15} \mathrm{~N}$ placement points to the subplot border. The holes were placed at an angle $30^{\circ}$ from the vertical using a piston steel rod with a diameter of $20 \mathrm{~mm}$. This was done to minimize damage to the plants within the subplots while drilling.

Plastic tubes were inserted into the holes of each subplot and ${ }^{15} \mathrm{NO}_{3}$ was injected into the soil as a solution of $\mathrm{Na}^{15} \mathrm{NO}_{3}$ (5 mg N mL ${ }^{-1}, 99 \%{ }^{15} \mathrm{~N}$ enriched). Each hole had $5 \mathrm{~mL}$ of ${ }^{15} \mathrm{NO}_{3}$ solution applied, that is, a total injection of $99 \mathrm{mg}{ }^{15} \mathrm{~N}$ to each subplot. The tubes were left for half an hour to allow the solution to be absorbed by the soil, followed by a $25-\mathrm{mL}$ application of demineralized water to each hole for rinsing. The tubes were removed after $1 \mathrm{~h}$ and a wooden rod (19-mm diam., $0.15-\mathrm{m}$ length) was inserted and left $0.10 \mathrm{~m}$ above the bottom of each hole to prevent roots from growing down the hole; the rods had been found to swell to a diameter of $20 \mathrm{~mm}$ after $24 \mathrm{~h}$ under humid conditions. The injection holes were covered to prevent rainwater from draining into the holes.

Soil water content at the time of the ${ }^{15} \mathrm{~N}$ injection experiment was $19.8,18.6,19.0,19.0$, and $16.5 \%$ of soil dry weight in $0.5-\mathrm{m}$ increments from the soil surface to $2.5-\mathrm{m}$ depth, which was close to field capacity. Based on these values, the ground water table was judged to be below the $2.5 \mathrm{~m}$-depth during the experiment.

\section{Plant Biomass and Soil Sampling}

Six days after ${ }^{15} \mathrm{~N}$ injection (31 Oct. -1 Nov. 2000), the aboveground plant biomass in each subplot was harvested for ${ }^{15} \mathrm{~N}$, total $\mathrm{N}$, and $\mathrm{C}$ analysis. Ryegrass and winter rye were cut $10 \mathrm{~mm}$ below the soil surface, and fodder radish, including the tap-root, was pulled from the ground. The plant samples were kept in plastic bags at $1^{\circ} \mathrm{C}$, rinsed in water to remove soil, chopped into coarse pieces, and dried at $80^{\circ} \mathrm{C}$ within a week after harvest. Additional samples of biomass of the three catch crop species were taken for analysis of background ${ }^{15} \mathrm{~N}$ levels in the plant material. Additional samples of biomass were taken immediately adjacent to the border of selected subplots (winter rye 1.4-m and fodder radish $2.5-\mathrm{m}$ depth of injection) to check for ${ }^{15} \mathrm{~N}$ uptake in the plants surrounding the subplots. The ${ }^{15} \mathrm{~N}$ enrichment in these samples was found to be within the range of the background ${ }^{15} \mathrm{~N}$ level.

On the day after harvesting was finished (2 Nov. 2000), soil was sampled for analysis of inorganic $\mathrm{N}$ content below the three catch crops. Nine replicate samples were taken randomly in each plot with a soil piston auger with an inner diameter of $14 \mathrm{~mm}$. The samples were divided into depth intervals of 0.25 or $0.5 \mathrm{~m}$ from the soil surface to $2.5-\mathrm{m}$ depth, and pooled to one composite sample for each depth and plot, making a total of four replicate samples per depth interval and species. The composite samples were thoroughly mixed, placed at $1^{\circ} \mathrm{C}$, and a subsample was frozen at $18^{\circ} \mathrm{C}$ within $24 \mathrm{~h}$ from sampling for later analysis.

\section{Sample and Data Analysis}

The samples of plant biomass were milled and a subsample was finely ground $(<0.5 \mathrm{~mm})$ and analyzed for ${ }^{15} \mathrm{~N}$, total $\mathrm{N}$, and $\mathrm{C}$ content on a Continuous Flow Isotope Ratio Mass Spectrometer consisting of an Automatic Nitrogen and Carbon Analyzer coupled to a 20-20 mass spectrometer (both Europa Scientific Ltd., Crewe, UK).

The ${ }^{15} \mathrm{~N}$ plant uptake was calculated from the ${ }^{15} \mathrm{~N}$ results, as the experimental design was equivalent to the "negative discard method" described by Powlson and Barraclough (1993). This method is different from the most common approach, which includes homogeneous application of ${ }^{15} \mathrm{~N}$ in a welldefined soil layer and detailed knowledge of the resulting ${ }^{15} \mathrm{~N}$ enrichment, neither of which is obtained with deep point ${ }^{15} \mathrm{~N}$ injection (Gass et al., 1971). Instead, the negative discard method requires that: (i) the crop is sampled from an area that is larger than the labeled area and judged to be sufficiently large to include any labeled $\mathrm{N}$ that could have moved outside the original application zone, and (ii) the entire sample is thoroughly mixed before subsampling for ${ }^{15} \mathrm{~N}$ analysis (Powlson and Barraclough, 1993). These requirements were met in the present experiment. A third requirement is of unlabeled $\mathrm{N}$ application outside plots at rates equal to ${ }^{15} \mathrm{~N}$ application rates inside experimental plots. This requirement was not met here, but since ${ }^{15} \mathrm{~N}$ application rates were low $\left(1.4 \mathrm{~kg} \mathrm{~N}^{-1}\right)$ compared with residual soil $\mathrm{N}$ pools (Table 1), the fertilizer effect of the ${ }^{15} \mathrm{~N}$ application could be regarded as negligible. The ${ }^{15} \mathrm{~N}$ plant uptake was calculated as excess plant ${ }^{15} \mathrm{~N}$ by subtraction of background ${ }^{15} \mathrm{~N}$ abundance determined for each species.

The frozen soil samples were thawed and $100 \mathrm{~g}$ fresh weight soil was immediately weighed and extracted in $1 \mathrm{M} \mathrm{KCl}$ for $1 \mathrm{~h}$ (soil/solution ratio 1:2). The soil extract was centrifuged and the supernatant was analyzed for $\mathrm{NH}_{4}$ and $\mathrm{NO}_{3}$ content by standard colorimetric methods using an AutoAnalyzer 3 (Bran+Luebbe, Germany). Soil water content was determined by drying at $60^{\circ} \mathrm{C}$ to constant weight. 
Table 1. Pools and concentrations of aboveground plant biomass $(n=16)$ and residual soil $\mathrm{NH}_{4}$ and $\mathrm{NO}_{3}$ pools $(n=4)$ calculated for the 0- to 1- and 1- to 2.5-m soil profile at the end of the ${ }^{15} \mathrm{~N}$ injection experiment on 1 November.

\begin{tabular}{|c|c|c|c|c|c|c|c|}
\hline & $\begin{array}{c}\text { Plant } \\
\text { biomass }\end{array}$ & Plant $N$ & Plant C & Plant $N$ & $\begin{array}{c}\text { Soil } \mathbf{N H}_{4} \\
0-2.5 ~ m\end{array}$ & $\begin{array}{c}\text { Soil NO }_{3} \\
\text { 0-1 m }\end{array}$ & $\begin{array}{c}\mathrm{Soil} \mathrm{NO}_{3} \\
\mathbf{1 - 2 . 5} \mathrm{m}\end{array}$ \\
\hline & $\mathbf{M g ~ h a}^{-1}$ & $\longrightarrow \mathbf{g}$ & & & $-\mathrm{kg}^{-}$ & $a^{-1}$ & \\
\hline \multirow{4}{*}{$\begin{array}{l}\text { Ryegrass (Lolium multiflorum Lam.) } \\
\text { Winter rye (Secale cereale L.) } \\
\text { Fodder radish (Raphanus sativus } \\
\text { L. var. oleiformis Pers.) }\end{array}$} & $4.29 \mathrm{a}(0.10) \dagger$ & 29.7a (0.7) & 411a (2) & 127.4a (4.2) & 21.5a (3.0) & 47.8a (5.6) & 39.1a (4.7) \\
\hline & $2.13 b(0.05)$ & $42.5 b(0.5)$ & 411a (4) & $90.5 b(2.2)$ & 19.7a (2.5) & 32.2a (4.1) & 27.2a (5.6) \\
\hline & & & & & & & \\
\hline & 3.96a (0.13) & $39.8 \mathrm{c}(0.8)$ & 378b (1) & $157.6 \mathrm{c}(6.1)$ & 17.8a (3.6) & $11.9 b(3.2)$ & $6.2 \mathrm{~b}(1.8)$ \\
\hline
\end{tabular}

$\dagger$ Numbers in parentheses indicate standard errors. Different letters indicate significant differences between means $(P<0.05)$.

Statistical significance of differences in root distribution, plant, and soil pools between species or soil layers was tested by analysis of variance (F-test), followed by pairwise comparisons by Tukey's student range test (Proc GLM, SAS Institute Inc., Cary, NC). All results were transformed before analysis by the function $y=\log (x)$ to obtain homogeneity of variance. To avoid observations that were negative or equal to zero, which cannot be log-transformed, 0.1 was added to root intensity and frequency and 0.2 to plant ${ }^{15} \mathrm{~N}$ uptake. In assessing differences between results, tests with $P<0.05$ were considered statistically significant.

\section{RESULTS}

\section{Plant and Soil Pools}

Plant dry matter harvested at the end of the ${ }^{15} \mathrm{~N}$ injection experiment was highest for ryegrass and fodder radish, with winter rye producing approximately half as much biomass (Table 1). The concentration of total $\mathrm{N}$ in the plant material decreased in the order winter rye, fodder radish, and ryegrass. When total plant biomass $\mathrm{N}$ was calculated on an area basis, it was highest in fodder radish followed by ryegrass and lowest in winter rye. The pools of $\mathrm{NH}_{4}$ left in the soils at the time of the ${ }^{15} \mathrm{~N}$ experiment did not differ between catch crop species $(P=0.65$; Table 1$)$. This was in contrast to the pools of $\mathrm{NO}_{3}$, which decreased in the order ryegrass $>$ winter rye $>$ fodder radish when calculated for both the 0 - to 1.0 - and 0 - to $2.5-\mathrm{m}$ soil profiles.

\section{Root Depth}

All three species differed in rate of root depth development. Winter rye and fodder radish were found to extend their average root depth to $>1$-m depth (Fig. 3a). Winter rye had reached $1 \mathrm{~m}$ by 16 October after an accumulative temperature of $977 \mathrm{~d}{ }^{\circ} \mathrm{C}$ from sowing, whereas fodder radish had already reached $1 \mathrm{~m}$ by 20 September, only $626 \mathrm{~d}{ }^{\circ} \mathrm{C}$ after sowing (Fig. 3b). Ryegrass had obtained an average root depth of $0.64 \mathrm{~m}$ just before the ${ }^{15} \mathrm{~N}$ injection experiment on 23 October, which increased to $0.76 \mathrm{~m}$ after termination of the ${ }^{15} \mathrm{~N}$ injection experiment on 3 November. Root depth of winter rye was 1.06 and $1.15 \mathrm{~m}$ on the two dates, while the fodder radish had obtained a root depth of $2.24 \mathrm{~m}$ by 23 October and $2.27 \mathrm{~m}$ by 3 November. However, the results for fodder radish were influenced by the fact that roots in at least three of the eight replicate minirhizotrons had reached the maximum measuring depth $(2.42 \mathrm{~m})$ of the minirhizotrons by 23 October. The lack of results below 2.42-m depth caused the average estimate of root depth to level off for the fodder radish by the last two measuring dates. These data points were therefore deleted from the regression analysis in Fig. 3b. The $r^{2}$ values of the regression analyses of root depth versus accumulated daily temperature from sowing were close to 1 , and the depth penetration rates were $0.8,1.3$, and $3.5 \mathrm{~mm} \mathrm{~d}^{-1}{ }^{\circ} \mathrm{C}^{-1}$ for ryegrass, winter rye, and fodder radish, respectively.

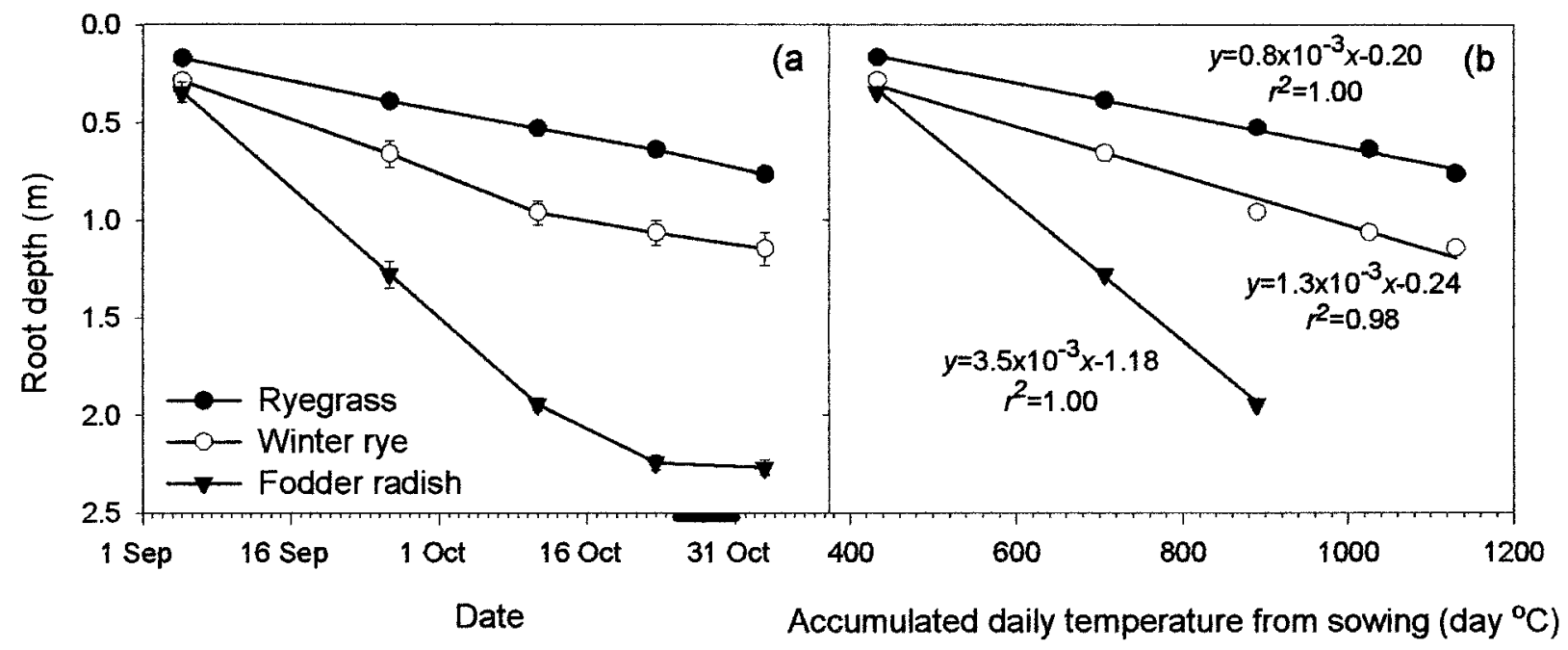

Fig. 3. Average root depth development versus (a) date and (b) accumulated daily temperature including regression outputs, from sowing of catch crops on 8 August. In (a) the horizontal bar on the $x$-axis indicates the 6-d period of the ${ }^{15} \mathrm{~N}$ injection experiment and the error bars indicate standard errors $(n=4)$. In $(b)$ the two last data points were deleted from the regression analysis for fodder radish due to root depth exceeding measuring depth of minirhizotrons. 


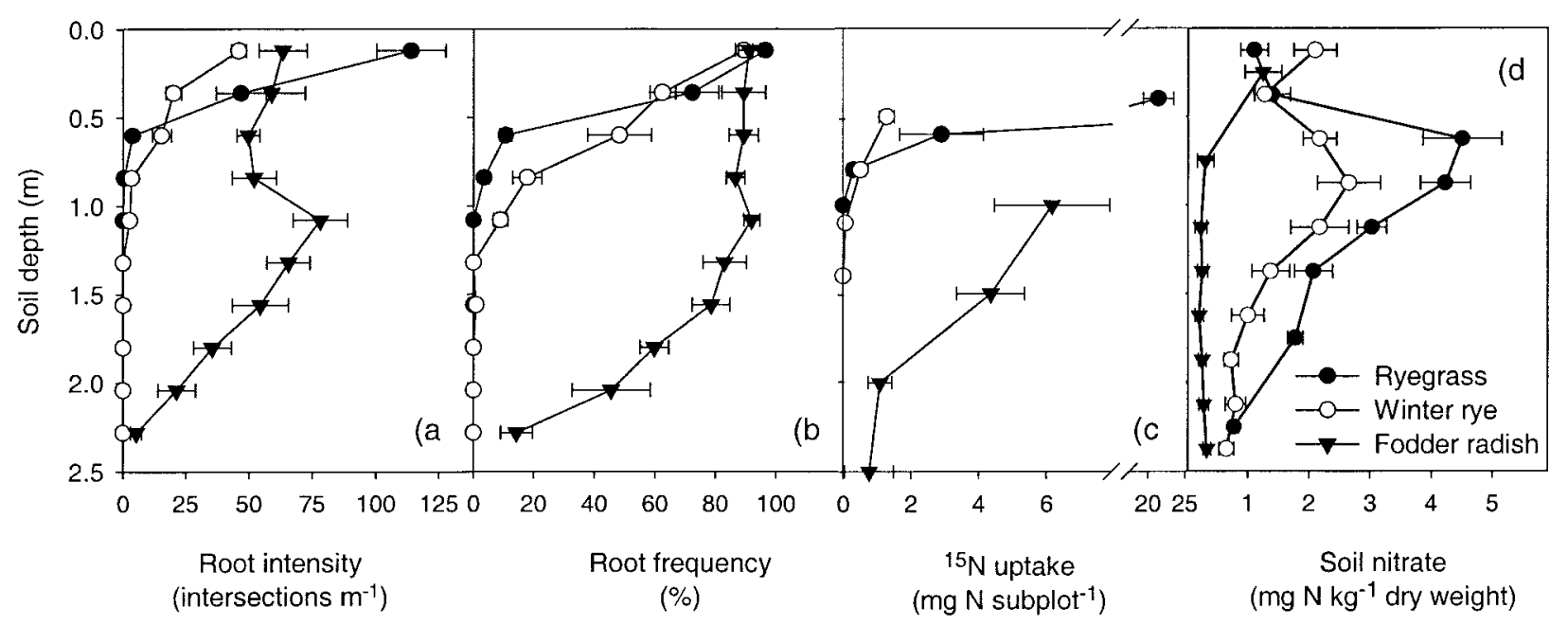

Fig. 4. Average (a) root intensity and (b) root frequency in the 0 - to $2.42-\mathrm{m}$ soil profile before the start of the ${ }^{15} \mathrm{~N}$ injection experiment; and (c) plant ${ }^{15} \mathrm{~N}$ uptake during the 6-d ${ }^{15} \mathrm{~N}$ injection experiment starting 25 October. Notice the break on the $x$-axis. Part (d) shows $\mathrm{NO}_{3}$ concentrations in the 0- to $2.5-\mathrm{m}$ soil profile. The error bars indicate standard errors $(n=4)$.

\section{Root Intensity and Frequency}

All the catch crops were found to have decreased root intensity with depth, but the pattern of root distribution was very different between the three catch crops at the time of the ${ }^{15} \mathrm{~N}$ injection experiment (Fig. 4a). Ryegrass had the highest root intensity of 114 intersections $\mathrm{m}^{-1}$ in the 0 - to $0.25-\mathrm{m}$ layer, decreasing to 4 intersections $\mathrm{m}^{-1}$ at 0.5 to $0.75 \mathrm{~m}$ and zero at 1 to $1.25 \mathrm{~m}$. Winter rye had the lowest root intensity of the three species in the 0 - to 0.25 - and 0.25 - to 0.5 -m layers with intensities of 46 and 20 intersections $\mathrm{m}^{-1}$, respectively. Intensity decreased to 3 at 1 to $1.25 \mathrm{~m}$ and zero at 1.25 to $1.5 \mathrm{~m}$, though a single root was observed in one minirhizotron at $1.5-\mathrm{m}$ depth. Fodder radish had a root intensity of 50 to 63 intersections $\mathrm{m}^{-1}$ in the 0 - to $1-\mathrm{m}$ layer and peaked at 78 intersections $\mathrm{m}^{-1}$ in the 1 - to $1.25-\mathrm{m}$ soil layer. However, this peak was not significantly higher than it was in the surrounding layers. Below $1.25 \mathrm{~m}$, root intensity gradually decreased to reach 5 intersections $\mathrm{m}^{-1}$ in the deepest soil layer.

For all three species, root frequency (Fig. 4b) in the 0 - to $0.25-\mathrm{m}$ layer was 90 to $96 \%$, decreasing to 11 and $0 \%$ for ryegrass at 0.5 to 0.75 and 1 to $1.25 \mathrm{~m}$. Winter rye root frequency decreased gradually to 48 and $9 \%$ in these two layers, while for fodder radish it was continuously high at 79 to $92 \%$ down to $1.5 \mathrm{~m}$, after which it gradually decreased to 46 and $14 \%$ at $2 \mathrm{~m}$ and below.

\section{Plant Nitrogen-15 Uptake}

For all three species, ${ }^{15} \mathrm{~N}$ uptake was highest at the shallowest ${ }^{15} \mathrm{~N}$ injection depths $(P<0.004)$, decreasing to zero or close to zero at the deepest injection depth (Fig. 4c). In general, 0 to $21 \%$ of added ${ }^{15} \mathrm{~N}$ was taken up during the $6 \mathrm{~d}$ of the experiment, and the ${ }^{15} \mathrm{~N}$ uptake profiles differed between the three species. The ${ }^{15} \mathrm{~N}$ uptake in ryegrass from the shallowest depth of $0.4 \mathrm{~m}$ was $21.4 \mathrm{mg} \mathrm{N}$ subplot $^{-1}$, decreasing sharply to $2.9,0.3$, and $0.0 \mathrm{mg} \mathrm{N}$ subplot $^{-1}$ at the 0.6-, 0.8-, and 1-m depths, respectively. The ${ }^{15} \mathrm{~N}$ uptake of winter rye from the shallowest injection depth of $0.5 \mathrm{~m}$ was only $1.3 \mathrm{mg} \mathrm{N}$ subplot $^{-1}$, decreasing gradually to $0.5,0.1$, and $0.0 \mathrm{mg} \mathrm{N}$ subplot $^{-1}$ at the 0.8-, 1.1-, and 1.4-m depths, respectively. For fodder radish, a ${ }^{15} \mathrm{~N}$ uptake of $6.2 \mathrm{mg} \mathrm{N}$ subplot ${ }^{-1}$ was observed at $1-\mathrm{m}$ depth, decreasing to $4.4,1.1$, and $0.8 \mathrm{mg} \mathrm{N}$ subplot $^{-1}$ at the 1.5-, 2-, and 2.5-m depths, respectively.

\section{Residual Soil Nitrate}

The distribution of soil $\mathrm{NO}_{3}$ in the 0 - to $2.5-\mathrm{m}$ soil profile differed among the catch crops at the time of the ${ }^{15} \mathrm{~N}$ injection experiment (Fig. 4d). Winter rye had left a higher concentration of $2.1 \mathrm{mg} \mathrm{NO} \mathrm{NO}_{3}-\mathrm{N} \mathrm{kg}^{-1}$ soil in the 0 - to $0.25-\mathrm{m}$ layer compared with ryegrass with $1.1 \mathrm{mg} \mathrm{NO}-\mathrm{N} \mathrm{kg}^{-1}$ soil $(P=0.04)$, whereas all three species had equal levels of 1.3 to $1.4 \mathrm{mg} \mathrm{NO}_{3}-\mathrm{N} \mathrm{kg}^{-1}$ soil in the 0.25 - to $0.5-\mathrm{m}$ layers (0- to $0.5-\mathrm{m}$ layer for fodder radish) (Fig. 4d). The $\mathrm{NO}_{3}$ concentration under ryegrass increased to a maximum value of $4.5 \mathrm{mg} \mathrm{N}$ $\mathrm{kg}^{-1}$ in the $0.5-$ to $0.75-\mathrm{m}$ layer, that is, significantly higher than under winter rye $(P=0.01)$. In the 1.25 to $1.5-\mathrm{m}$ layer, the concentration decreased to $2.1 \mathrm{mg} \mathrm{N}$ $\mathrm{kg}^{-1}$, that is, still significantly higher than under fodder radish but not compared with winter rye $(P<0.05)$. Winter rye showed a similar peak in $\mathrm{NO}_{3}$ concentration of $2.7 \mathrm{mg} \mathrm{NO}-\mathrm{N} \mathrm{kg}^{-1}$ around the 0.75 - to 1 -m layer followed by a decrease to 0.7 - to $1.0 \mathrm{mg} \mathrm{NO}-\mathrm{N} \mathrm{kg}^{-1}$ in the 1.5- to 2.5-m layer. The $\mathrm{NO}_{3}$ level under fodder radish was found to be at a constant low level of 0.2 to $0.3 \mathrm{mg} \mathrm{N} \mathrm{kg}{ }^{-1}$ in the 0.5 - to 2.5 -m layers, which was significantly lower than for winter rye and ryegrass at all comparable layers. Ammonium levels were found to be at the same level under the three catch crops with values of 1.3 to $1.8 \mathrm{mg} \mathrm{NH}_{4}-\mathrm{N} \mathrm{kg}^{-1}$ in the 0 - to $0.5-\mathrm{m}$ layer and 0.1 to $0.6 \mathrm{mg} \mathrm{NH} \mathrm{NH}_{4}-\mathrm{N} \mathrm{kg}^{-1}$ in the layers from 0.5 to $2.5 \mathrm{~m}$ (results not shown).

\section{Regression Analysis of Nitrogen-15 Uptake and Root Distribution}

Regression analyses were performed between the amount of ${ }^{15} \mathrm{~N}$ plant uptake from the four ${ }^{15} \mathrm{~N}$ injection 


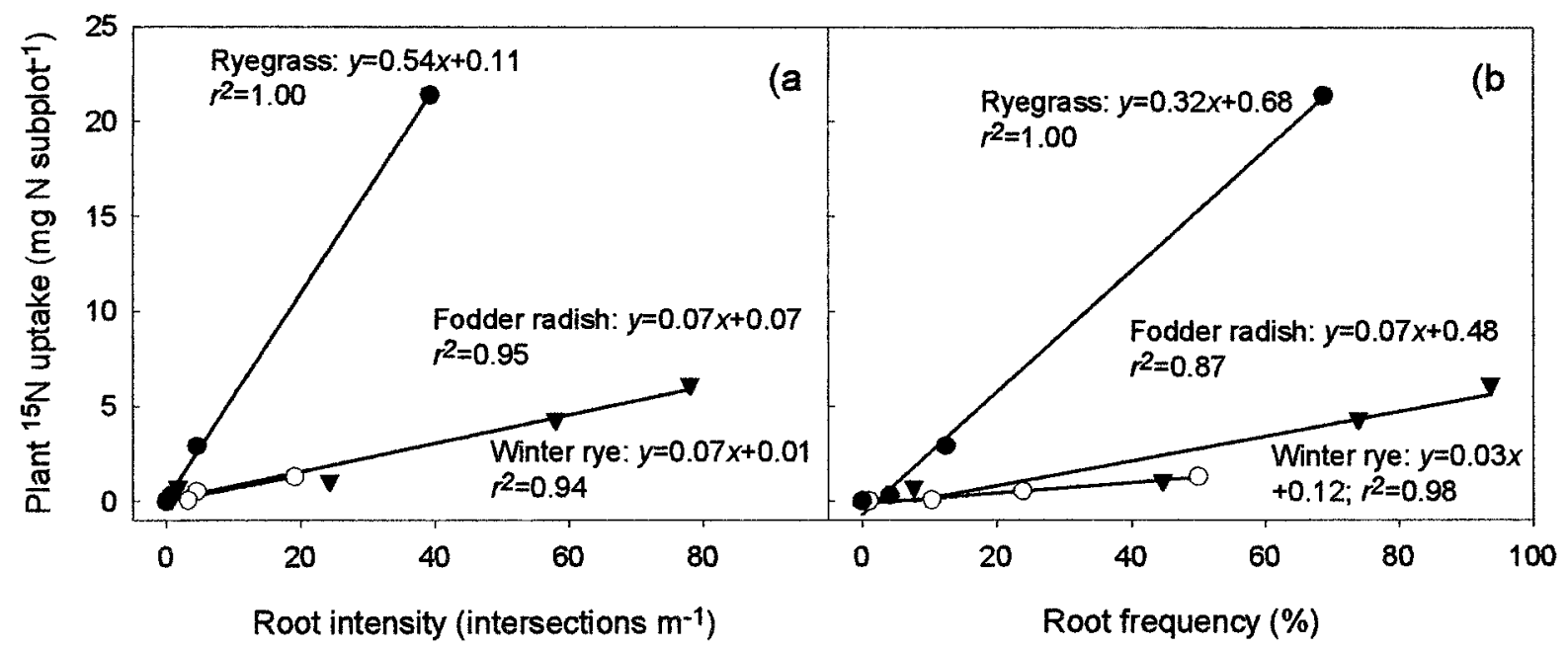

Fig. 5. Plant ${ }^{15} \mathrm{~N}$ uptake during the 6-d ${ }^{15} \mathrm{~N}$ injection experiment versus (a) root intensity and (b) root frequency in a $0.2-\mathrm{m}$ soil layer surrounding each ${ }^{15} \mathrm{~N}$ injection point. Regression outputs are shown $(n=4)$.

depths for each species and root intensity or frequency in the $0.2-\mathrm{m}( \pm 0.1 \mathrm{~m})$ soil layer surrounding the point of ${ }^{15} \mathrm{~N}$ injection (Fig. 5a,b). Good correlation $\left(r^{2}=0.94\right.$ 1.00) was found between both ${ }^{15} \mathrm{~N}$ plant uptake and root intensity as well as between ${ }^{15} \mathrm{~N}$ plant uptake and root frequency $\left(r^{2}=0.87-1.00\right)$.

\section{DISCUSSION}

\section{Relationship Between Minirhizotron Results and Nitrogen-15 Uptake}

The estimates of root depth obtained with the minirhizotrons were confirmed by the ${ }^{15} \mathrm{~N}$ uptake of the catch crops as well as by the soil profiles of residual soil $\mathrm{NO}_{3}$ (Fig. 4c,d). In the deepest ${ }^{15} \mathrm{~N}$ placement under winter rye and ryegrass, ${ }^{15} \mathrm{~N}$ was placed below the observed root depth, and no ${ }^{15} \mathrm{~N}$ uptake was recorded in the aboveground biomass (Fig. 4c). However, when ${ }^{15} \mathrm{~N}$ was placed above the observed root depth, or even at the bottom of the root zone $(0.8 \mathrm{~m}$ for ryegrass, $1.1 \mathrm{~m}$ for winter rye, and $2.5 \mathrm{~m}$ for fodder radish), an uptake of ${ }^{15} \mathrm{~N}$ was always observed.

It has been suggested that only part of a root system may be active in $\mathrm{N}$ uptake at any one time (Robinson et al., 1991), and that the activity level of each root may change over time (Henriksen et al., 1992) along with root growth and distribution. These changes can be triggered by changes in local N supply (Van Vuuren et al., 1996; Hodge et al., 1999). At the scale of whole root systems in the field it is nevertheless reasonable to expect a fairly linear relationship between root density in different soil layers and plant $\mathrm{N}$ uptake from those layers, under conditions such as in the present experiment. These conditions include a sudden excess $\mathrm{N}$ supply in the given soil volume as well as measurements of ${ }^{15} \mathrm{~N}$ uptake over a few days. The linear relationship is expected because the quantity of roots is thought to be a major factor governing plant $\mathrm{N}$ uptake under these conditions (Robinson, 1986). Such a linear relationship was found in the regression analysis of plant ${ }^{15} \mathrm{~N}$ uptake and root intensity shown in Fig. 5a. Several studies have shown that root intensities observed with the minirhizotron method often do not correlate well with root length densities determined by soil sampling and root extraction techniques, and the validity of the minirhizotron technique has been questioned on this basis (e.g., Parker et al., 1991; Heeraman and Juma, 1993). The good correlation between plant $\mathrm{N}$ uptake and root intensity obtained with minirhizotrons in this study, however, shows that the minirhizotron methodology gave information on root distribution that was meaningful in terms of the ability of the root systems to take up $\mathrm{NO}_{3}$ from different depths.

It should be kept in mind that the root intensities at the ${ }^{15} \mathrm{~N}$ injection points covaried with depth for all species. The relationship could therefore be related to differences in depth instead of root intensity. With larger injection depth, the distance that ${ }^{15} \mathrm{~N}$ must be transported through the root system to aboveground plant parts increases. The effect on ${ }^{15} \mathrm{~N}$ uptake could therefore be the result of slow translocation of ${ }^{15} \mathrm{~N}$ relative to the distance between shallow and deep injection depths, as only $6 \mathrm{~d}$ were allowed for ${ }^{15} \mathrm{~N}$ uptake and translocation before sampling of aboveground plant parts. Nitrogen can be translocated from root to shoot within a matter of hours or a few days (Rao et al., 1993; Rossato et al., 2001), but the rate of translocation depends among other factors on species, transpiration, and C-supply, most of which were unknown in this experiment. Comparison of ${ }^{15} \mathrm{~N}$ uptake profiles for the three species, however, does not indicate an influence of injection depths. In this case a plot of ${ }^{15} \mathrm{~N}$ uptake against injection level (medium, low, and very low root abundance) for each species would show a steeper gradient the greater the distance between injection depths. These were 0.2, 0.3 , and $0.5 \mathrm{~m}$ for ryegrass, winter rye, and fodder radish, respectively. Instead, the steepest gradient was found in ryegrass and the flattest in winter rye (results not shown).

\section{Root Intensity and Frequency Measures}

A high linear correlation was found not only for plant ${ }^{15} \mathrm{~N}$ uptake and root intensity but also for root frequency 
(Fig. 5b). Use of the root frequency measurement (Thorup-Kristensen, 2001) is based on the theory that just a few roots is sufficient for depletion of $\mathrm{NO}_{3}$ in a given soil layer because of the high mobility of the ion in soil solution (Robinson, 1986). Over the short term and under excess $\mathrm{NO}_{3}$ availability, as in the present study, it can be expected that root intensity will correlate better than root frequency with $\mathrm{N}$ uptake, because the number of roots will be the limiting factor for $\mathrm{NO}_{3}$ uptake. However, this assumes that the $\mathrm{N}$ demand of the plant is high (Robinson, 1986), which may not have been the case here. A relatively low plant $\mathrm{N}$ demand was indicated by the high biomass $\mathrm{N}$ concentrations for winter rye and fodder radish of 4.25 and $3.98 \%$, respectively (Table 1), compared with 2.94 and $2.86 \%$ in another study with relatively high $\mathrm{N}$ supply (ThorupKristensen, 2001). Furthermore, high amounts of residual $\mathrm{N}$ were left within the root zone of winter rye and ryegrass, which indicated adequate $\mathrm{N}$ supply during the growing season (Fig. 4d, Table 1). Another cause of the equally good correlation between ${ }^{15} \mathrm{~N}$ uptake and root intensity or frequency could be the strong covariation between root intensity and root frequency. Thus, under the conditions of the present study, root frequency was found to be a useful alternative to root intensity as a measure of root distribution in the study of plant $\mathrm{N}$ uptake. This was also found by Thorup-Kristensen (2001) when studying residual soil $\mathrm{NO}_{3}$ under catch crops. Root frequency has the advantage that it can be measured much more quickly than root intensity, which demands counting of all roots along the minirhizotron grid.

\section{Root Depth and Distribution}

The use of long minirhizotrons reaching a depth of $2.42 \mathrm{~m}$ revealed that the three catch crops had very different root development, that is, shallow (ryegrass), intermediate (winter rye), and deep (fodder radish) rooted species (Fig. 3a). The results for the three species concur with the conclusion of Thorup-Kristensen (2001) that crucifers are characterized by faster root depth development compared with monocots, and are in accordance with studies showing a larger maximum root depth in many dicots than in monocots (Kutschera and Lichtenegger, 1982, 1992; Sun et al., 1997). The root depth penetration rates of 0.8 and $1.3 \mathrm{~mm} \mathrm{~d}^{-1}{ }^{\circ} \mathrm{C}^{-1}$ found for ryegrass and winter rye (Fig. 3b) were comparable with those of 1.1 and $1.2 \mathrm{~mm} \mathrm{~d}^{-1}{ }^{\circ} \mathrm{C}^{-1}$ for the two species on the same soil during two subsequent years when similar root methodology was used (Thorup-Kristensen, 2001). The root depth penetration rate of $3.5 \mathrm{~mm}$ $\mathrm{d}^{-1}{ }^{\circ} \mathrm{C}^{-1}$ for fodder radish (Fig. 3b) was higher than penetration rates of 2.0 and 2.3 previously reported for fodder radish and winter rape, another cruciferous species. In this previous study, however, minirhizotrons only reached $1.2 \mathrm{~m}$ (Thorup-Kristensen, 2001). The discrepancy between the results for fodder radish could be due to the very fast root development of this species, since the use of shorter minirhizotrons allowed only a short period for measurement before the roots reached the bottom of the minirhizotrons.
The differences between the two monocots and fodder radish were also evident in the distribution of roots in the soil profile, with monocots having the highest root intensity in the surface soil layer, declining gradually to the bottom of the root zone (Fig. 4a). Contrary to the monocots, fodder radish showed consistently higher root intensity from the soil surface to $1.5-\mathrm{m}$ depth. Similar differences between monocot and dicot species have been found by Materechera et al. (1993).

\section{Catch Crop Efficiency for Nitrate Uptake}

The fodder radish had practically depleted the soil of $\mathrm{NO}_{3}$ down to $2.5-\mathrm{m}$ depth at the time of the ${ }^{15} \mathrm{~N}$ experiment, leaving only $18 \mathrm{~kg} \mathrm{NO}_{3}-\mathrm{N}^{-1}$ compared with $87 \mathrm{~kg} \mathrm{NO}_{3}-\mathrm{N} \mathrm{ha}^{-1}$ under ryegrass (Table 1). This showed that fodder radish is a very efficient catch crop for soil $\mathrm{N}$ depletion. Much of the difference was found below a depth of $1 \mathrm{~m}$, which is the maximum measuring depth in most root and residual soil $\mathrm{N}$ studies. Based on results from the 0- to 1-m layer, the efficiency of fodder radish in depleting $\mathrm{NO}_{3}$ was $36 \mathrm{~kg} \mathrm{~N}$ ha ${ }^{-1}$ higher than that of ryegrass with an additional difference of $33 \mathrm{~kg} \mathrm{~N}^{-1}$ in the 1- to 2.5-m layer. This emphasizes the importance of choosing the right measuring depth for studies of $\mathrm{N}$ leaching and cycling depending on the root depth of the plant species under study.

Ryegrass left much $\mathrm{NO}_{3}$ at the border of its root zone in the 0.5 - to 1-m soil layer (Fig. 4d), but less in the soil layers below $1 \mathrm{~m}$. The lower amount of residual $\mathrm{NO}_{3}$ left below the root zone indicated that $\mathrm{NO}_{3}$ had been low there from the beginning of the growing season. Winter rye was more efficient for $\mathrm{NO}_{3}$ retention than ryegrass, even below the $1.5-\mathrm{m}$ depth, which is below the root depth of winter rye (Fig. 4d). This could be due to leaching of soil solution with lower $\mathrm{NO}_{3}$ concentration from the root zone.

In general, root depth of the catch crops was found to be a good indicator of how effective the catch crops were in depleting $\mathrm{NO}_{3}$, whereas aboveground biomass $\mathrm{N}$ was not. No correlation was found between this pool and residual soil $\mathrm{NO}_{3}$ under the three catch crops (Table 1). The discrepancy between amounts of $\mathrm{NO}_{3}$ taken from the soil and $\mathrm{N}$ found in aboveground biomass can probably be explained by differences in $\mathrm{N}$ pools such as root systems (Jackson et al., 1993) and dead soil organic matter originating from leaves shedded during growth (Rossato et al., 2001). Based on the relationship between root depth and $\mathrm{NO}_{3}$ depletion there is reason to believe that other species with deep root depth penetration may be efficient as catch crops for $\mathrm{N}$ uptake from deep soil layers, for example, winter rape (ThorupKristensen, 2001). When designing crop rotations these deep-rooted species should be used where high amounts of $\mathrm{N}$ have been leached to deeper soil layers. Many fields have tile drains at $1 \mathrm{~m}$-depth, which remove large amounts of soil solution after the ground water table rises in winter. The major proportion of catch crop $\mathrm{N}$ uptake takes place during autumn, however, when the ground water table is much deeper. Nitrate taken up by deep-rooted catch crops below the root zone of the 
following crop therefore represents a net input of $\mathrm{N}$ into the system that would otherwise have been lost through leaching. The use of deep-rooted catch crops could therefore substantially improve the $\mathrm{N}$ use efficiency of crop rotations.

\section{Root Lengths and Nitrogen Inflows}

Root intensity estimated by counting the number of roots intersecting with the grid on the minirhizotron surface can be used for estimation of root-length density (Heeraman and Juma, 1993). This was done following the modified Newman-line-intersect method for estimating root length (Tennant, 1975), and by assuming a depth of view of $2 \mathrm{~mm}$ into the soil surrounding the minirhizotron to calculate the volumetric root-length density (Taylor et al., 1970; Heeraman and Juma, 1993). Total root lengths were estimated to be 17,31 , and $92 \mathrm{~km} \mathrm{~m}^{-2}$ for winter rye, ryegrass, and fodder radish, respectively. For comparison, values of 5, 12, 19 to 29, and 11 to $25 \mathrm{~km} \mathrm{~m}^{-2}$ for sugarbeet, winter barley, winter wheat, and winter rape, respectively, have been found in field studies by other methods (profile wall and soil coring) (Barraclough and Leigh, 1984; Barraclough, 1989; Strebel and Duynisveld, 1989). The root-length density of $92 \mathrm{~km} \mathrm{~m}^{-2}$ for fodder radish seems very high. The maximum root-length densities of 5 to $6 \mathrm{~cm} \mathrm{~cm}^{-3}$ calculated for 0.25 -m soil layers under fodder radish (results not shown), however, are in range with values found in other field studies for fodder radish $(6 \mathrm{~cm}$ $\mathrm{cm}^{-3}$ ) (Vos et al., 1998) and winter rape (4 and $10 \mathrm{~cm}$ $\mathrm{cm}^{-3}$ ) (Barraclough, 1989; Vos et al., 1998). The very high estimate of total root length may therefore be the result of high root-length density extending to deep depths.

The ${ }^{15} \mathrm{~N}$ uptake profiles for the three catch crops can be used to make a rough calculation of plant $\mathrm{N}$ uptake rates from a given soil volume (Table 2). It was assumed that ${ }^{15} \mathrm{~N}$ at each injection point was distributed in $1 \mathrm{~L}$ of soil. The ${ }^{15} \mathrm{~N}$ enrichment in this soil volume was then adjusted for the dilution effect of the soil $\mathrm{NO}_{3}$ pool

Table 2. Total plant $\mathbf{N}$ uptake rates, root lengths, and $\mathbf{N}$ inflow rates at depths of ${ }^{15} \mathrm{~N}$ injection.

\begin{tabular}{|c|c|c|c|}
\hline Injection depth & $\mathbf{N}$ uptake rate $\dagger$ & Root length $L(v)+$ & $\mathbf{N}$ inflow \\
\hline $\mathbf{m}$ & mg N kg soil ${ }^{-1} \mathbf{d}^{-1}$ & $\mathbf{c m ~} \mathbf{c m}^{-3}$ & pmol $\mathbf{m}^{-1} \mathbf{s}^{-1}$ \\
\hline \multicolumn{4}{|c|}{ Ryegrass } \\
\hline 0.4 & 0.77 & 3.09 & 33.3 \\
\hline 0.6 & 0.12 & 0.36 & 46.0 \\
\hline 0.8 & 0.01 & 0.05 & 33.9 \\
\hline 1.0 & 0.00 & 0.00 & - \\
\hline \multicolumn{4}{|c|}{ Winter rye } \\
\hline 0.5 & 0.05 & 1.50 & 3.9 \\
\hline 0.8 & 0.02 & 0.36 & 6.9 \\
\hline 1.1 & 0.01 & 0.26 & 1.2 \\
\hline 1.4 & 0.00 & 0.01 & - \\
\hline \multicolumn{4}{|c|}{ Fodder radish } \\
\hline 1.0 & 0.22 & 6.13 & 4.9 \\
\hline 1.5 & 0.16 & 4.56 & 4.7 \\
\hline 2.0 & 0.04 & 1.91 & 2.8 \\
\hline 2.5 & 0.03 & 0.14 & 27.6 \\
\hline
\end{tabular}

$\dagger$ Calculated on basis of ${ }^{15} \mathrm{~N}$ results after correction for residual soil $\mathrm{NO}_{3}$ and root biomass $\mathbf{N}$. Assumptions are given in the text.

$¥$ Calculated from minirhizotron results in the 0 .2-m soil layer surrounding injection points. Assumptions and calculation details are given in the text. (atom \% assumed to be natural abundance of $0.366 \%$ $\left.{ }^{15} \mathrm{~N}\right)$. Root/shoot N ratios found by Jackson et al. (1993) of $0.27,0.17$, and 0.38 for ryegrass, winter rye, and fodder radish, respectively, were used to include root biomass ${ }^{15} \mathrm{~N}$ in total plant $\mathrm{N}$ uptake rates for the 6 -d period. The $\mathrm{N}$ uptake rates and root length densities were used for calculating $\mathrm{N}$ inflow rates at the depths at which ${ }^{15} \mathrm{~N}$ was injected (Table 2). Fodder radish showed inflow rates in the 1-, 1.5-, and 2-m depths of 3 to $5 \mathrm{pmol} \mathrm{m}^{-1}$ $\mathrm{s}^{-1}$, whereas the rate at $2.5-\mathrm{m}$ depth was one order of magnitude higher. These rates are all in range with those of 4 to $22 \mathrm{pmol} \mathrm{m}^{-1} \mathrm{~s}^{-1}$ found for winter rape in the 0 - to 0.2-m soil layer during spring and summer (Barraclough, 1989). An explanation for the higher inflow from $2.5-\mathrm{m}$ depth under fodder radish could be that the roots had reached this soil layer within the week immediately before ${ }^{15} \mathrm{~N}$ injection. All roots were therefore young and had recently been active in the uptake of small amounts of available $\mathrm{NO}_{3}$ (Fig. 4d). In contrast, the rest of the root system consisted of roots of different age occupying soil layers that had probably been depleted of $\mathrm{NO}_{3}$. Age and $\mathrm{NO}_{3}$ conditions can strongly influence a root's ability to take up $\mathrm{NO}_{3}$ (Lainé et al., 1993).

The $\mathrm{N}$ inflow rates found for winter rye were in range with those of fodder radish from the 1-, 1.5-, and 2-m depths, as were those for winter barley and winter wheat (Strebel and Duynisveld, 1989), while Barraclough (1986) found inflows to be one order of magnitude higher for winter wheat. The similar inflow rates for winter rye and fodder radish show that the low recovery of ${ }^{15} \mathrm{~N}$ by winter rye (Fig. 4c) was an effect of its low root density compared with the other two species. Ryegrass had root densities at the injection depths in range with winter rye, but ryegrass showed $\mathrm{N}$ inflow rates one order of magnitude higher than winter rye and in range with the rate for fodder radish at $2.5-\mathrm{m}$ depth. A maximum $\mathrm{N}$ inflow rate for perennial ryegrass of $15 \mathrm{pmol}$ $\mathrm{m}^{-1} \mathrm{~s}^{-1}$ was found in a laboratory experiment (Hodge et al., 1999), and similar or higher $\mathrm{N}$ inflow rates have been found in field experiments; for example, for sugarbeet, rates of 44 to $104 \mathrm{pmol} \mathrm{m}^{-1} \mathrm{~s}^{-1}$ (Strebel and Duynisveld, 1989), and, for 10 maize cultivars, rates of 14 to $257 \mathrm{pmol} \mathrm{m}^{-1} \mathrm{~s}^{-1}$ (Wiesler and Horst, 1994).

None of the three catch crops showed any tendency toward reduced $\mathrm{N}$ inflow rates with depth, thus supporting the notion that the 6-d experimental period from ${ }^{15} \mathrm{~N}$ injection to plant sampling was sufficient to ensure translocation of ${ }^{15} \mathrm{~N}$ to plant shoots as discussed above.

\section{CONCLUSIONS}

There was good agreement between estimates of root depth and distribution found using the minirhizotron method and results of ${ }^{15} \mathrm{~N}$ uptake by the three catch crops: ryegrass, winter rye, and fodder radish. We therefore conclude that the minirhizotron method as applied in the present work is useful when studying root depth and distribution in relation to studies of plant $\mathrm{N}$ uptake.

Differences in root depth were significant in the ability of catch crops to absorb N. It is therefore crucial that the entire root zone of species is measured if the 
effects on $\mathrm{NO}_{3}$ leaching of different catch crop species are to be compared. Nitrate depletion in deeper soil layers (below $1 \mathrm{~m}$ ) could be substantial. To increase $\mathrm{N}$ use efficiency of crop rotations, the $\mathrm{NO}_{3}$ taken up by deep-rooted catch crops below the root zone of the following crop is especially important. It represents a net input of $\mathrm{N}$ to the system, which would otherwise have been lost through leaching. The knowledge on root depth and $\mathrm{N}$ uptake from deeper soil layers can be used in the design of crop rotations to improve $\mathrm{N}$ use efficiency.

\section{ACKNOWLEDGMENTS}

This work was supported by the Danish Agricultural and Veterinary Research Council. We thank Birthe R. Flyger, Astrid Bergmann, Jens Jørgen Jensen, Jens Elkjær, Jens Barfod, and Jytte Christiansen for skillful technical assistance.

\section{REFERENCES}

Barraclough, P.B. 1986. The growth and activity of winter wheat roots in the field: Nutrient inflows of high-yielding crops. J. Agric. Sci. 106:53-59.

Barraclough, P.B. 1989. Root growth, macro-nutrient uptake dynamics and soil fertility requirements of a high-yielding winter oilseed rape crop. Plant Soil 119:59-70.

Barraclough, P.B., and R.A. Leigh. 1984. The growth and activity of winter wheat roots in the field: The effect of sowing date and soil type on root growth of high-yielding crops. J. Agric. Sci. 103:59-74.

Borg, H., and D.W. Grimes. 1986. Depth development of roots with time: An empirical description. Trans. ASAE 29:194-197.

Canadell, J., R.B. Jackson, J.R. Ehleringer, H.A. Mooney, O.E. Sala, and E.D. Schulze. 1996. Maximum rooting depth of vegetation types at the global scale. Oecologia 108:583-595.

Gass, W.B., G.A. Peterson, R.D. Hauck, and R.A. Olson. 1971. Recovery of residual nitrogen by corn (Zea mays L.) from various soil depths as measured by ${ }^{15} \mathrm{~N}$ tracer techniques. Soil Sci. Soc. Am. Proc. 35:290-294.

Heeraman, D.A., and N.G. Juma. 1993. A comparison of minirhizotron, core and monolith methods for quantifying barley (Hordeum vulgare L.) and fababean (Vicia faba L.) root distribution. Plant Soil 148:29-41.

Henriksen, G.H., D.R. Raman, L.P. Walker, and R.M. Spanswick. 1992. Measurement of net fluxes of ammonium and nitrate at the surface of barley roots using ion-selective microelectrodes. II. Patterns of uptake along the root axis and evaluation of the microelectrode flux estimation technique. Plant Physiol. 99:743-747.

Hodge, A., D. Robinson, B.S. Griffiths, and A.H. Fitter. 1999. Why plants bother: Root proliferation results in increased nitrogen capture from an organic patch when two grasses compete. Plant Cell Environ. 22:811-820.

Huang, Y., D.H. Rickerl, and K.D. Kephart. 1996. Recovery of deeppoint injected soil nitrogen-15 by switchgrass, alfalfa, ineffective alfalfa, and corn. J. Environ. Qual. 25:1394-1400.

Jackson, L.E., L.J. Wyland, and L.J. Stivers. 1993. Winter cover crops to minimize nitrate losses in intensive lettuce production. J. Agric. Sci. 121:55-62.

Kuhlmann, H., P.B. Barraclough, and A.H. Weir. 1989. Utilization of mineral nitrogen in the subsoil by winter wheat. Z. Pflanzenernaehr. Bodenkd. 152:291-295.

Kutschera, L., and E. Lichtenegger. 1982. Wurzelatlas mitteleuropäischer Grünlandpflanzen, Bd. 1 Monocotyledoneae. (In German.) Gustav Fischer, Stuttgart, Jena, N.Y.

Kutschera, L., and E. Lichtenegger. 1992. Wurzelatlas mitteleuropäischer Grünlandpflanzen, Bd. 2 Pteridophyta und Dicotyledoneae (Magnoliopsida), Teil 1 Morphologie, Anatomie, Ökologie,
Verbreitung, Soziologie, Wirtschaft. (In German.) Gustav Fischer, Stuttgart, Jena, N.Y.

Lainé, P., A. Ourry, J. Macduff, J. Boucaud, and J. Salette. 1993. Kinetic parameters of nitrate uptake by different catch crop species: Effects of low temperatures or previous nitrate starvation. Physiol. Plant. 88:85-92.

Materechera, S.A., A.M. Alston, J.M. Kirby, and A.R. Dexter. 1993. Field evaluation of laboratory techniques for predicting the ability of roots to penetrate strong soil and of the influence of roots on water sorptivity. Plant Soil 149:149-158.

Meisinger, J.J., W.L. Hargrove, R.L. Mikkelsen, J.R. Williams, and V.W. Benson. 1991. Effects of cover crops on groundwater quality. p. 57-68. In Cover crops for clean water: The proceedings of an international conference, West Tennessee Exp. Stn., 9-11 Apr. 1991, Jackson, Tennessee.

Parker, C.J., M.K.V. Carr, N.J. Jarvis, B.O. Puplampu, and V.H. Lee. 1991. An evaluation of the minirhizotron technique for estimating root distribution in potatoes. J. Agric. Sci. 116:341-350.

Peterson, G.A., F.N. Anderson, G.E. Varvel, and R.A. Olson. 1979. Uptake of ${ }^{15} \mathrm{~N}$-labeled nitrate by sugarbeets from depths greater than $180 \mathrm{~cm}$. Agron. J. 71:371-372.

Powlson, D.S., and D. Barraclough. 1993. Mineralization and assimilation in soil-plant systems. p.209-242. In R. Knowles and T.H. Blackburn (ed.) Nitrogen isotope techniques. Academic Press, Inc., San Diego, CA.

Rao, T.P., O. Ito, and R. Matsunga. 1993. Differences in uptake kinetics of ammonium and nitrate in legumes and cereals. Plant Soil 154:67-72.

Richards, I.R., P.A. Wallace, and I.D.S. Turner. 1996. A comparison of six cover crop types in terms of nitrogen uptake and effect on response to nitrogen by a subsequent spring barley crop. J. Agric. Sci. 127:441-449.

Robinson, D. 1986. Limits to nutrient inflow rates in roots and root systems. Physiol. Plant. 68:551-559.

Robinson, D., D.J. Linehan, and S. Caul. 1991. What limits nitrate uptake from soil? Plant Cell Environ. 14:77-85.

Rossato, L., P. Laine, and A. Ourry. 2001. Nitrogen storage and remobilization in Brassica napus L. during the growth cycle: Nitrogen fluxes within the plant and changes in soluble protein patterns. J. Exp. Bot. 52:1655-1663.

Smit, A.L., E. George, and J. Groenwold. 2000. Root observations and measurements at (transparent) interfaces with soil. p.235-271. In A.L. Smit et al. (ed.). Root methods. A handbook. Springer, Berlin.

Strebel, O., and W.H.M. Duynisveld. 1989. Nitrogen supply to cereals and sugar beet by mass flow and diffusion on a silty loam soil. Z. Pflanzenernaehr. Bodenkd. 152:135-141.

Sun, G., D.P. Coffin, W.K. Lauenroth, and G.W. Sun. 1997. Comparison of root distributions of species in North American grasslands using GIS. J. Veg. Sci. 8:587-596.

Taylor, H.M., M.G. Huck, B. Klepper, and Z.F. Lund. 1970. Measurement of soil-grown roots in a rhizotron. Agron. J. 62:807-809.

Tennant, D. 1975. A test of a modified line intersect method of estimating root length. J. Ecol. 63:995-1001.

Thorup-Kristensen, K. 2001. Are differences in root growth of nitrogen catch crops important for their ability to reduce soil nitrate $\mathrm{N}$ content, and how can this be measured? Plant Soil 230:185-195.

Thorup-Kristensen, K., J. Magid, and L.S. Jensen. 2003. Catch crops and green manures as biological tools in nitrogen management in temperate zones. Adv. Agron. 79:227-302.

Van Vuuren, M.M.I., D. Robinson, and B.S. Griffiths. 1996. Nutrient inflow and root proliferation during the exploitation of a temporally and spatially discrete source of nitrogen in soil. Plant Soil 178: 185-192.

Vos, J., P.E.L. van der Putten, M.H. Hussein, A.M. van Dam, and P.A. Leffelaar. 1998. Field observations on nitrogen catch crops: II. Root length and root length distribution in relation to species and nitrogen supply. Plant Soil 201:149-155.

Wiesler, F., and W.J. Horst. 1994. Root growth and nitrate utilization of maize cultivars under field conditions. Plant Soil 163:267-277. 